Tropical Journal of Pharmaceutical Research January 2017; 16 (1): 193-201

ISSN: $1596-5996$ (print); 1596-9827 (electronic)

(c) Pharmacotherapy Group, Faculty of Pharmacy, University of Benin, Benin City, 300001 Nigeria.

All rights reserved.

Available online at http://www.tjpr.org

Original Research Article

http://dx.doi.org/10.4314/tjpr.v16i1.26

\title{
Synthesis and in vivo anti-hyperlipidemic activity of novel n-benzoylphenyl-2-furamide derivatives in Wistar rats
}

\author{
Suhair Hikmat ${ }^{1}$, Tariq Al-qirim ${ }^{1 \star}$, Dania Alkabbani ${ }^{1}$, Ghassan Shattat ${ }^{2}$, Ghassan \\ Abu Sheikha ${ }^{1}$, Dima Sabbah ${ }^{1}$, Reema Abu khalaf ${ }^{1}$ and Yusuf Al-hiari ${ }^{3}$ \\ ${ }^{1}$ Faculty of Pharmacy, Al-Zaytoonah University of Jordan, Amman, Jordan, ${ }^{2}$ College of Science and Health Professions, King \\ Saud Bin Abdulaziz University for Health Sciences, Riyadh, Saudi Arabia, ${ }^{3}$ Faculty of Pharmacy, University of Jordan, Amman, \\ Jordan
}

*For correspondence: Email: tariq.qirim@zuj.edu.jo; Tel: 009624291511; Fax: 0096264291432

Received: 19 September 2016

Revised accepted: 15 December 2016

\begin{abstract}
Purpose: To synthesize and evaluate the anti-hyperlipidemic activity of a novel series of $\mathrm{N}$ (benzoylphenyl)-2-furamides (3a, 3b, $\mathbf{4 a}, \mathbf{4 b}$ and $\mathbf{4 c}$ ).

Methods: Compounds (3a, 3b, 4a, $\mathbf{4 b}$ and $\mathbf{4 c}$ ) were successfully synthesized by reacting activated furan-2-carbonyl-chloride derivatives with aminobenzophenones at $60^{\circ} \mathrm{C}$ for $36 \mathrm{~h}$. Hyperlipidemia was induced in overnight fasted rats by intraperitoneal administration of Triton WR-1339 (300 mg/kg). to overnight fasted rats. The rats were divided into six groups: control, hyperlipidemic, hyperlipidemic plus compounds $\mathbf{3 b}, \mathbf{4 b}, \mathbf{4 c}$, and hyperlipidemic plus bezafibrate-treated. Eighteen hours later, blood samples were collected and plasma lipid profile determined using enzymatic methods.

Results: At a dose of $15 \mathrm{mg} / \mathrm{kg}$ body weight, the elevated plasma triglyceride (TG) levels, total cholesterol (TC) and low density lipoprotein cholesterol (LDL-C) levels were significantly reduced by compounds $4 b(p<0.001)$ and $4 c(p<0.0001) 18 h$ later, compared to the hyperlipidemic group. Furthermore, compounds $\mathbf{4 b}$ and $\mathbf{4 c}$ significantly increased high density lipoprotein cholesterol (HDL-C) levels by 29 and $34 \%$, respectively.

Conclusion: The findings indicate the high potency of $\mathrm{N}$-(benzolphenyl)-2-furamides (4b and $\mathbf{4 c}$ ) as lipid-lowering agents. Thus, these compounds $\mathbf{4 b}$ and $\mathbf{4 c}$ may used as lead compounds for the development of new derivatives and agents for targeting dyslipidemia and cardiovascular diseases.
\end{abstract}

Keywords: Triton WR-1339-induced hyperlipidemic rats, $N$-(benzoylphenyl)-2-furamides, Lipid-lowering activity, Cardiovascular disease, Synthesis

Tropical Journal of Pharmaceutical Research is indexed by Science Citation Index (SciSearch), Scopus, International Pharmaceutical Abstract, Chemical Abstracts, Embase, Index Copernicus, EBSCO, African Index Medicus, JournalSeek, Journal Citation Reports/Science Edition, Directory of Open Access Journals (DOAJ), African Journal Online, Bioline International, Open-J-Gate and Pharmacy Abstracts

\section{INTRODUCTION}

Cardiovascular diseases have become a major health problem in developing countries. Hyperlipidemia is defined as high levels of lipids (fat, cholesterol and triglycerides) circulating in the bloodstream [1,2]. Epidemiological studies demonstrate that hyperlipidemia is the most prevalent indicator of susceptibility to atherosclerosis and heart diseases [3-5]. Thus, decreasing plasma lipid levels play a major role in the treatment and prevention of coronary heart diseases [6]. For this reason, many studies have been conducted to evaluate the potential lipidlowering activity of synthetic and naturally compounds.

Triton WR-1339, a non-ionic detergent (oxyethylated tertiary octylphenol formaldehyde polymer) has been widely used in in vivo studies to produce acute hyperlipidemia in animal models in order to study the lipid-lowering effect 
of natural or chemical drugs [7]. Triton WR-1339 has been found to prevent the catabolism of triglycerol-rich lipoprotein by lipoprotein lipase $[8,9]$.

There are many classes of lipid-lowering agents in existence. Fibrates and their derivatives including bezafibrate are class of drugs widely used to treat hypertriglyceridemia [10]. Bezafibrate significantly reduces serum triglyceride and free fatty acid levels [11]. The major mechanism of fibrates is by the induction of lipoprotein lipase and efficient reduction of apolipoprotein C-III-containing particles, which are markers for increased risk of atherosclerosis [12-14].

In the last decade, many studies have shown that furan derivatives have promising potentials as lipid-lowering agents [15-17]. Therefore, the present study focuses on the synthesis and pharmacological evaluation of a novel series of $\mathrm{N}$-(benzoylphenyl)-2-furamides as models for their lipid-lowering activity (Figure 1).

\section{EXPERIMENTAL}

\section{Materials and methods}

All chemicals, reagents and solvents were of analytical grade and used directly without further purification. Chemicals and solvents were purchased from the corresponding companies (Sigma-Aldrich; St. Louis, MO, USA and Acros; Belgium).

Melting points (MP) were recorded using Gallenkamp melting point apparatus and were uncorrected. Infrared (IR) spectra were recorded using Shimadzu IR Affinity-1 spectrophotometer. All samples were prepared as potassium bromide (Acros, Belgium) discs. ${ }^{1} \mathrm{H}$ and ${ }^{13} \mathrm{C}$ NMR spectra were recorded using Bruker $300 \mathrm{MHz}$ (Avance III, Switzerland Department of chemistry, the University of Jordan). Chemical Shifts are given in $\delta$ units using TMS as an internal reference. Chemical shifts are given in $\delta$ (ppm) using TMS as internal reference; deuterated solvents were used and stated with each compound. Thin Layer Chromatography (TLC) was performed on $20 \times 20 \mathrm{~cm}$ aluminum plates pre-coated with fluorescent silica gel GF254 (Fluka, Germany) and visualized by UV light (at 254 and/or $360 \mathrm{~nm}$ ).

\section{Synthesis of the targeted compounds}

5-(3-Hydroxyphenyl) furan-2-carboxylic acid (2): methyl-5-(3-hydroxyphenyl) furan-2-carboxylate (1) $(1 \mathrm{~g}, 4.58 \mathrm{mmol})$ was treated with $10 \mathrm{~mL}$ of 10 $\%$ sodium hydroxide solution $(6 \mathrm{~N})$ at $90{ }^{\circ} \mathrm{C}$ for $24 \mathrm{~h}$. Then, the solution was neutralized with 10 $\%$ hydrochloric acid $(2 \mathrm{~N})$, under ice conditions. The crude solid was filtered to afford methyl-5-(3hydroxyphenyl) furan-2-carboxylic acid (2) as a white powder.

5-(3-Hydroxyphenyl) furan-2-carbonyl chloride (3): 5-(3-hydroxyphenyl) furan-2-carboxylic acid (2) $(0.75 \mathrm{~g}, 3.675 \mathrm{mmol})$ was treated with oxalyl chloride $(0.63 \mathrm{~mL}, 7.2 \mathrm{mmol})$. Thereafter, the solution was refluxed for $48 \mathrm{~h}$ and then evaporated under reduce pressure. The crude product was then co-evaporated twice with (10 $\mathrm{mL}$ ) benzene to give 5-(3-hydroxyphenyl) furan2-carbonyl chloride (3) as pale yellow solid.

$\mathrm{N}$-(4-Benzoylphenyl)-5-(3-hydroxyphenyl)-2furamide (3a): 5-(3-hydroxyphenyl) furan-2carbonyl chloride (3) $(0.5 \mathrm{~g}, 2.10 \mathrm{mmol})$ was dissolved in $10 \mathrm{~mL}$ dichloromethane (DCM). Then $100 \mathrm{mg}$ of 4-(dimethylamino) pyridine (DMAP) was added. The mixture was stirred at room temperature for $15 \mathrm{~min}$. Then $0.82 \mathrm{~g}, 4.20$ mmol of 4-aminobenzophenon and $10 \mathrm{~mL} \mathrm{~N}, \mathrm{~N}$ dimethylformamide (DMF) were added to the reaction mixture.<smiles>O=C(c1ccccc1)c1ccc(NC(=O)c2ccc(-c3cccc(O)c3)o2)cc1</smiles>

(3a)<smiles>Cc1ccc(C(=O)Nc2ccc(C(=O)c3ccccc3)cc2)o1</smiles>

(4a)

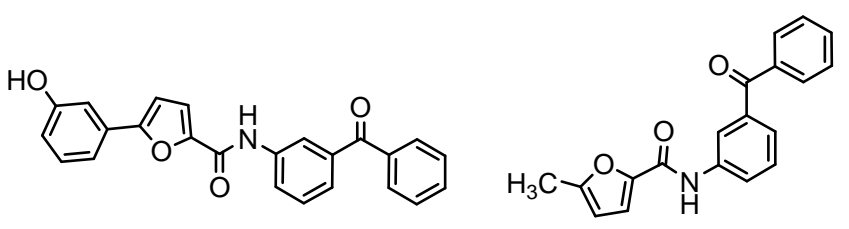

(3b) (4b)



(4c)

Figure 1: Chemical structures of novel $N$-(benzoylphenyl)-2-furamides (3a, 3b, 4a, 4b and 4c) 
The reaction mixture was heated at $60^{\circ} \mathrm{C}$ for 36 $h$. Solvents were evaporated and the residue was purified by column chromatography using chloroform (100\%) as eluent to afford the targeted compound (3a) as a fine yellow solid.

N-(3-Benzoylphenyl)-5-(3-hydroxyphenyl)-2-

furamide (3b): 5-(3-hydroxyphenyl) furan-2carbonyl chloride (3) $(0.5 \mathrm{~g}, 2.10 \mathrm{mmol})$ was dissolved in $10 \mathrm{~mL}$ of dichloromethane. Then, $100 \mathrm{mg}$ of 4-(dimethylamino) pyridine was added. The mixture was stirred at room temperature for $15 \mathrm{~min}$. Then $(0.829 \mathrm{~g}, 4.206$ $\mathrm{mmol}$ ) of 3-aminobenzophenon and $10 \mathrm{~mL}$ of $\mathrm{N}$, $\mathrm{N}$ dimethylformamide were added to the reaction mixture. The reaction mixture was heated at 60 ${ }^{\circ} \mathrm{C}$ for $36 \mathrm{~h}$. Solvents were evaporated and the residue was purified by column chromatography using chloroform (100\%) as eluent to afford the targeted compound (3b) as a fine yellow solid.

$\mathrm{N}$-(4-Benzoylphenyl)-5-methyl-2-furamide (4a): 5-methylfuran-2-carbonyl chloride (4) $(0.5 \mathrm{~g}, 3.45$ $\mathrm{mmol})$ was dissolved in $(10 \mathrm{ml})$ of dichloromethane. Then, $100 \mathrm{mg}$ of 4(dimethylamino) pyridine was added. The mixture was stirred at room temperature for $15 \mathrm{~min}$. Then, $(1.36 \mathrm{~g}, \quad 6.91 \mathrm{mmol})$ of 4aminobenzophenon was added to the reaction mixture. The reaction mixture was heated at 60 ${ }^{\circ} \mathrm{C}$ for $24 \mathrm{~h}$. DCM was evaporated and the residue was purified by column chromatography using chloroform/methanol (80:20) as eluent to afford the targeted compound (4a) as a white powder.

$\mathrm{N}$-(3-Benzoylphenyl)-5-methyl-2-furamide (4b): 5-methylfuran-2-carbonyl chloride (4) (1g, 6.91 $\mathrm{mmol})$ was dissolved in $(10 \mathrm{~mL})$ of dichloromethane. Then, $100 \mathrm{mg}$ of 4(dimethylamino) pyridine was added. The mixture was stirred at room temperature for $15 \mathrm{~min}$. Then $(2.72 \mathrm{~g}, 13.83 \mathrm{mmol})$ of 3-aminobenzophenon was added to the reaction mixture. The reaction mixture was heated at $60{ }^{\circ} \mathrm{C}$ for $24 \mathrm{~h}$. DCM was evaporated and the residue was purified by column chromatography using chloroform/methanol (80:20) as eluent to afford the targeted compound (4b) as a white powder.

$\mathrm{N}$-(2-Benzoylphenyl)-5-methyl-2-furamide (4c): 5-methylfuran-2-carbonyl chloride (4) $(0.8 \mathrm{~g}, 5.53$ $\mathrm{mmol})$ was dissolved in $(10 \mathrm{~mL})$ of dichloromethane. Then, $100 \mathrm{mg}$ of 4(dimethylamino) pyridine was added. The mixture was stirred at room temperature for $15 \mathrm{~min}$. Then $(2.18 \mathrm{~g}, 11.06 \mathrm{mmol})$ of 2-aminobenzophenon was added to the reaction mixture. The reaction mixture was heated at $60{ }^{\circ} \mathrm{C}$ for $24 \mathrm{~h}$. DCM was evaporated and the residue was purified by column chromatography using chloroform/methanol (80:20) as eluent to afford the targeted compound (4c) as a white powder.

\section{Animals and treatments}

Male Wistar rats weighing $180 \mathrm{~g}$ were obtained from the animal house of the Faculty of Pharmacy, Al-Zaytoonah University of Jordan. The animals were provided ad libitum access only to tap water throughout the experimental duration and maintained in a $12 \mathrm{~h} \mathrm{light-dark}$ cycle under standard laboratory conditions $\left(22 \pm 2{ }^{\circ} \mathrm{C}\right)$.

Principles of laboratory animal care as described in the European Community guidelines were followed [18]. All experiments were approved by the Animal Welfare Committee of the University (approval ref no. 6ZAWC/2016).

\section{Triton model of hyperlipidemia}

Acute hyperlipidemia was developed in animals by intraperitoneal administration of Triton WR1339 (Tyloxapol, Sigma-Aldrich) to the rats at a dose of (300 mg/kg body weight) [19].

\section{Determination of anti-hyperlipidemic activity}

After injection of Triton, the overnight fasted rats were randomly divided into six groups of eight animals each. Normal control group (NCG) received an intraperitoneal administration of normal saline; hyperlipidemic control group $(\mathrm{HCG})$ received an intraperitoneal injection of Triton WR-1339 dissolved in distilled water. In the third, fourth and fifth groups, hyperlipidemic rats were given intragastrically $(15 \mathrm{mg} / \mathrm{kg}$ body weight) of compounds $\mathbf{3 b}, \mathbf{4 b}$ and $\mathbf{4 c}$ respectively.

In the last group the hyperlipidemic rats were given intragastrically (100 mg/kg body weight) of bezafibrate (BF) [20,21]. At $18 \mathrm{~h}$ following triton administration animals were anaesthetized and blood samples were collected from the renal artery. The blood samples were immediately centrifuged (3000 rpm for $10 \mathrm{~min}$ ) and the serum was used for lipid profile analysis by an enzymatic method with an automated analyzer (Model Erba XL-300, Mannheim, Germany).

\section{Statistical analysis}

All anti-hyperlipidemic activity data are presented as mean \pm SEM $(n=8)$. The data were analyzed using Student's t-test, and $p<0.05$ was 
considered statistically significant (SPSS version 2015, IBM SPSS Statistics).

\section{RESULTS}

\section{Chemistry}

According to the proposed aims, a series of $N$ (benzoylphenyl)-5-(3-hydroxyl phenyl)-2furamide ( $\mathbf{3 a}$ and $\mathbf{3 b}$ ) were synthesized starting from methyl-5-(3-hydroxyphenyl)furan-2carboxylate (1) as shown in Scheme 1. Two different aminobenzophenone substitutions were used, 4-aminobenzophenone for compound $\mathrm{N}$ (4-benzoylphenyl)-5-(3-hydroxyphenyl)-2furamide (3a), and 3-aminobenzophenone for $\mathrm{N}$ (3-benzoylphenyl)-5-(3-hydroxyphenyl)-2furamide (3b).

At the same time, a series of $N$-(benzoylphenyl)5-methyl-2-furamide (4a, $\mathbf{4 b}$ and $\mathbf{4 c})$ were synthesized starting from 5-methylfuran-2carbonylchloride (4) as shown in (Scheme 2). Three different aminobenzophenone substitutions were used, 4-aminobenzophenone for compound $\mathrm{N}$-(4-benzoylphenyl)-5-methyl-2furamide (4a), 3-aminobenzophenone for $\mathrm{N}$-(3benzoylphenyl)-5-methyl-2-furamide (4b), and 2aminobenzophenone for $\mathrm{N}$-(2-benzoylphenyl)-5methyl-2-furamide (4c).

\section{N-(4-Benzoylphenyl)-5-(3-hydroxyphenyl)-2- furamide (3a)}

Yield $34 \%$; m.p.: $198-200{ }^{\circ} \mathrm{C} ; \quad R_{f}: 0.33$ $\left.\left(\mathrm{CHCl}_{3}\right) / \mathrm{MeOH}, 98: 2\right)$; IR (KBr) $\mathrm{cm}^{-1}: 3263(\mathrm{~N}-\mathrm{H})$,
$3055(\mathrm{O}-\mathrm{H}), 1689$ (CO, ketone), 1651 (CO, amide), 1597, 1527, 1411, 1311, 1280, 1180, $925,848,786,702,594,509,424,385 \mathrm{~cm}^{-1} .1 \mathrm{H}-$ NMR (500 Hz, d6-DMSO) $\delta$ (ppm): 10.52 (br, s, $1 \mathrm{H}, \mathrm{CONH}), 8.38$ (s, 1H, OH), 7.96 (s, 1H, Ar-H), $7.71(\mathrm{~d}, \mathrm{~J}=1.35 \mathrm{~Hz}, 1 \mathrm{H}$, furan- $\mathrm{H}), 7.66(\mathrm{~m}, 6 \mathrm{H}$, Ar-H), $7.55(\mathrm{~m}, 3 \mathrm{H}, \operatorname{Ar}-\mathrm{H}), 7.38$ (d, J = 8.45 Hz, $1 \mathrm{H}$, furan-H), $7.25(\mathrm{~m}, 1 \mathrm{H}, \mathrm{Ar}-\mathrm{H}), 6.6(\mathrm{~m}, 2 \mathrm{H}, \mathrm{Ar}-$ H); 13C-NMR (d6-DMSO): $\delta=195.3$ (1C), 160.7 (1C), 142.7 (1C), 137.9 (2C), 132.8 (2C), 132.3 (1C), 132.2 (1C), 132.7 (2C), 129.8 (2C), 128.9 (4C), 128.4 (1C), 127.6(1C), 127.0 (1C), 119.0 (2C), 116.8 (1C), 116.6 (1C) ppm.

\section{N-(3-Benzoylphenyl)-5-(3-hydroxyphenyl)-2- furamide (3b)}

Yield: 32 \%; m.p.: 200-202 ${ }^{\circ} \mathrm{C} ; \quad \mathrm{R}_{\mathrm{f}}$ : 0.30 $\left(\mathrm{CHCl}_{3} / \mathrm{MeOH}, 98: 2\right)$; IR (KBr) $\mathrm{cm}^{-1}$ : $3549(\mathrm{~N}-\mathrm{H})$, $3278(\mathrm{O}-\mathrm{H}), 1680$ (CO, ketone), 1658 (CO, amide), 1589, 1543, 1481, 1435, 1404, 1311, 1280, 1165, 1126, 979, 902, 864, 786, 717, 648, 594. 1H-NMR $\left(300 \mathrm{~Hz}, \mathrm{CDCl}_{3}\right) \delta(\mathrm{ppm}): 8.85$ (br, $\mathrm{s}, 1 \mathrm{H}, \mathrm{CONH}), 8.74(\mathrm{~s}, 1 \mathrm{H}, \mathrm{OH}), 8,48(\mathrm{~s}, 1 \mathrm{H}, \mathrm{Ar}-$ $\mathrm{H}), 8.34(\mathrm{~d}, \mathrm{~J}=3.0 \mathrm{~Hz}, 1 \mathrm{H}$, furan-H), 7.96 (d, J = $9.0 \mathrm{~Hz}, 1 \mathrm{H}$, furan-H), $7.87(\mathrm{~s}, 1 \mathrm{H}, \operatorname{Ar}-\mathrm{H}), 7.76(\mathrm{~m}$, $3 \mathrm{H}, \mathrm{Ar}-\mathrm{H}), 7.67(\mathrm{~m}, 2 \mathrm{H}, \mathrm{Ar}-\mathrm{H}), 7.51$ (m, 6H, Ar$\mathrm{H})$; 13C-NMR $\left(\mathrm{CDCl}_{3}\right) \delta(\mathrm{ppm})$ : 196.6 (1C), 162.6 (1C), 159.7 (1C), 139.1 (1C), 138.3 (1C), 137.5 (1C), 137.4 (1C), 137.1 (1C), 137.0 (1C), 133.0 (1C), 132.8 (1C), 130.1 (2C), 129.7 (1C), 129.1 (1C), 128.5 (1C), 128.4(2C), 126.8 (1C), 126.4 (1C), 124.0 (1C), 122.4 (1C), 121.1 (1C), 119.6 (1C).

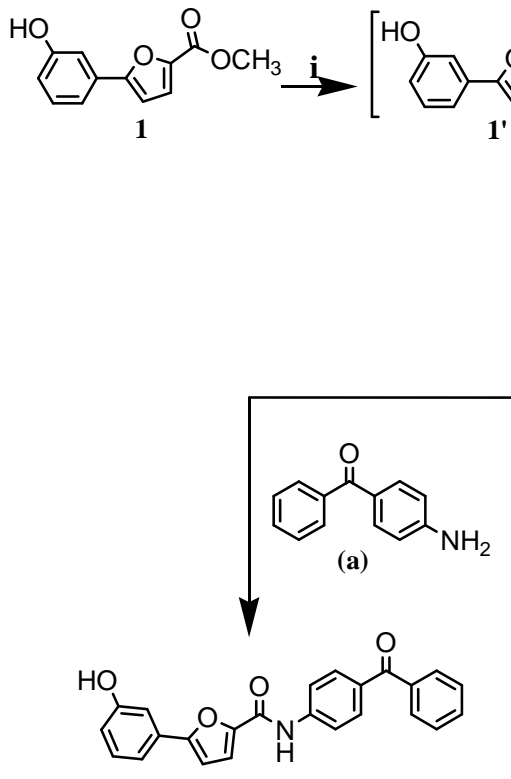

(3a)

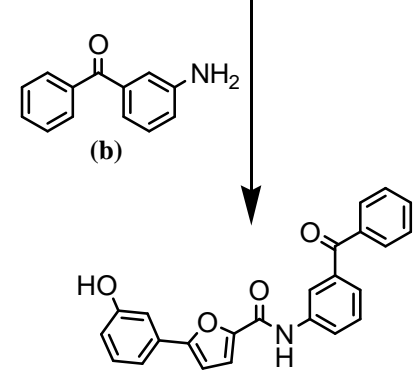

(3b) 
Scheme 1: Synthesis of $\mathrm{N}$-(benzoylphenyl)-5-(3-hydroxylphenyl)-2-furamide (3a, 3b). Reagents and conditions: (i): $\mathrm{NaOH} 10 \%$ solution (6N)/reflux, $24 \mathrm{~h}$; (ii): $\mathrm{HCl}\left(0^{\circ} \mathrm{C}\right)$; (iii): $\mathrm{C}_{2} \mathrm{O}_{2} \mathrm{Cl}_{2}, \mathrm{DCM} / \mathrm{reflux}\left(50^{\circ} \mathrm{C}\right), 48 \mathrm{~h}$; (iv): DMAP, DMF, $\left(60^{\circ} \mathrm{C}\right), 36 \mathrm{~h}$

\section{N-(4-Benzoylphenyl)-5-methyl-2-furamide (4a)}

Yield: $45 \%$; m.p.: $106-108{ }^{\circ} \mathrm{C} ; \quad \mathrm{R}_{\mathrm{f}}: 0.5$ $\left(\mathrm{CHCl}_{3} / \mathrm{MeOH}, 98: 2\right)$; IR (KBr) cm$)^{-1}: 3533(\mathrm{~N}-\mathrm{H})$, $3008\left(\mathrm{CH}_{3}\right), 1666.52$ (CO, ketone), 1666.50 (CO, amide), 1589, 1519, 1404, 1319, 1280, 1249, $1211,1134,1018,925,848,794,748,702,624$, 509. $1 \mathrm{H}-\mathrm{NMR}\left(500 \mathrm{~Hz}, \mathrm{CDCl}_{3}\right) \delta(\mathrm{ppm}): 8.20(\mathrm{br}$, s, $1 \mathrm{H}, \mathrm{CONH}), 7.88(\mathrm{~d}, \mathrm{~J}=8.65 \mathrm{~Hz}, 2 \mathrm{H}, \mathrm{Ar}-\mathrm{H})$, $7.81(\mathrm{~m}, 4 \mathrm{H}, \mathrm{Ar}-\mathrm{H}), 7.60(\mathrm{t}, \mathrm{J}=7.4 \mathrm{~Hz}, 1 \mathrm{H}, \mathrm{Ar}-\mathrm{H})$, 7.54 (t, J = $8 \mathrm{~Hz}, 2 \mathrm{H}, \operatorname{Ar}-\mathrm{H}), 7.20(\mathrm{~d}, \mathrm{~J}=3.35$ $\mathrm{Hz}, 1 \mathrm{H}$, furan- $\mathrm{H}), 6.21(\mathrm{~d}, \mathrm{~J}=2.65 \mathrm{~Hz}, 1 \mathrm{H}$, furan$\mathrm{H}), 2.43 \mathrm{ppm}\left(\mathrm{s}, 3 \mathrm{H}, \mathrm{CH}_{3}\right) ; 13 \mathrm{C}-\mathrm{NMR}\left(\mathrm{CDCl}_{3}\right)$ $\delta(\mathrm{ppm}): 195.6$ (1C), 156.2 (1C), 155.4 (1C), 145.8(1C), 141.6 (1C), 137.9 (1C), 133.0 (1C), $132.2(1 \mathrm{C}), 131.6(2 \mathrm{C}), 129.8(2 \mathrm{C}), 128.3(2 \mathrm{C})$, 118.8(2C), 117.4 (1C), 109.3 (1C), 13.9 (1C).

\section{N-(3-Benzoylphenyl)-5-methyl-2-furamide (4b)}

Yield: 38 \%: m.p.: $105-106{ }^{\circ} \mathrm{C}$; $\mathrm{R}_{\mathrm{f}}: 0.55\left(\mathrm{CHCl}_{3}\right.$ $/ \mathrm{MeOH}, 98: 2)$; IR (KBr) cm${ }^{-1}: 3564(\mathrm{~N}-\mathrm{H}), 3062$ $(\mathrm{CH} 3), 1674.21$ (CO, ketone), 1674.20(CO, amide), 1597, 1519, 1481, 1427, 1357, 1319, 1288, 1211, 1080, 1018, 964, 902, 871, 786, 725, 586, 509. $1 \mathrm{H}-\mathrm{NMR}\left(500 \mathrm{~Hz}, \mathrm{CDCl}_{3}\right) \delta(\mathrm{ppm})$ : $8.17(\mathrm{br}, \mathrm{s}, 1 \mathrm{H}, \mathrm{CONH}), 8.12(\mathrm{~d}, \mathrm{~J}=1.0 \mathrm{~Hz}, 1 \mathrm{H}$, Ar-H), $7.93(\mathrm{~s}, 1 \mathrm{H}, \mathrm{Ar}-\mathrm{H}), 7.84$ (d, J = $1.3 \mathrm{~Hz}, 2 \mathrm{H}$, Ar-H), 7.62 (t, J = 7.4Hz, 1H, Ar-H), $7.57(\mathrm{~d}, \mathrm{~J}=$ $7.7 \mathrm{~Hz}, 1 \mathrm{H}, \mathrm{Ar}-\mathrm{H}), 7.51$ (t, J = $7 \mathrm{~Hz}, 3 \mathrm{H}, \mathrm{Ar}-\mathrm{H})$, $7.17(\mathrm{~d}, \mathrm{~J}=3.35 \mathrm{~Hz}, 1 \mathrm{H}$, furan- $\mathrm{H}), 6.19(\mathrm{~d}, \mathrm{~J}=2.6$ $\mathrm{Hz}, 1 \mathrm{H}$, furan- $\mathrm{H}), 2.42 \mathrm{ppm}\left(\mathrm{s}, 3 \mathrm{H}, \mathrm{CH}_{3}\right) ; 13 \mathrm{C}-$ NMR $\left(\mathrm{CDCl}_{3}\right) \delta(\mathrm{ppm}): 196.2(1 \mathrm{C}), 156.3$ (1C), 155.2 (1C), 145.8(1C), 138.3 (1C), 137.7 (1C), 137.3 (1C), 132.6 (1C), 130.1 (2C), 129.1 (1C),
$128.3(2 \mathrm{C}), \quad 125.9(1 \mathrm{C}), 123.8(1 \mathrm{C}), 121.0(1 \mathrm{C})$, 117.0 (1C), $109.2(1 \mathrm{C}), 13.9(1 \mathrm{C})$.

\section{N-(2-Benzoylphenyl)-5-methyl-2-furamide (4c)}

Yield: $35 \%$ : m.p.: $102-103{ }^{\circ} \mathrm{C}$; Rf; $0.7(\mathrm{CHCl} 3$ $/ \mathrm{MeOH}, 98: 2)$; IR (KBr) cm-1: $3317(\mathrm{~N}-\mathrm{H}), 3124$ $(\mathrm{CH} 3), 1674.21$ (CO, ketone), 1620.21(CO, amide), 1597, 1519, 1489, 1435, 1357, 1311, $1288,1211,1134,1103,1018,925,871,802$, 748, 694, 632, 516, 447, 385. 1H-NMR $(400 \mathrm{~Hz}$, $\mathrm{CDCl} 3) \delta(\mathrm{ppm}): \delta=11.72(\mathrm{br}, \mathrm{s}, 1 \mathrm{H}, \mathrm{CONH}), 8.79$ (d, J = 8.0 Hz,1H, furan-H), $7.72(\mathrm{~d}, \mathrm{~J}=8.0 \mathrm{~Hz}$, $2 \mathrm{H}, \mathrm{Ar}-\mathrm{H}), 7.60(\mathrm{t}, \mathrm{J}=12.0 \mathrm{~Hz}, 3 \mathrm{H}, \mathrm{Ar}-\mathrm{H}), 7.26(\mathrm{~s}$, $2 \mathrm{H}, \operatorname{Ar}-\mathrm{H}), 7.18(\mathrm{~d}, \mathrm{~J}=4.0 \mathrm{~Hz}, 1 \mathrm{H}, \mathrm{Ar}-\mathrm{H}), 7.10$ (t, $\mathrm{J}=8.0 \mathrm{~Hz}, 1 \mathrm{H}, \operatorname{Ar}-\mathrm{H}), 6.15(\mathrm{~d}, \mathrm{~J}=4.0 \mathrm{~Hz} 1 \mathrm{H}$, furan-H), $2.45 \mathrm{ppm}(\mathrm{s}, 3 \mathrm{H}, \mathrm{CH} 3) ; 13 \mathrm{C}-\mathrm{NMR}$ $(\mathrm{CDCl} 3) \delta(\mathrm{ppm}): \delta=199.6(1 \mathrm{C}), 156.9(1 \mathrm{C})$, 155.7 (1C), 146.27 (1C), 140.4 (1C), 138.8 (1C), 134.2 (1C), 133.7 (1C), 132.2 (2C), 129.7 (1C), $128.2(2 \mathrm{C}), 123.2(1 \mathrm{C}), 121.9(1 \mathrm{C}), 121.4(1 \mathrm{C})$, 116.7 (1C), 108.7 (1C), 13.9 (1C).

\section{Anti-hyperlipidemic activity}

The plasma total cholesterol (TC), triglyceride (TG), high-density lipoprotein-cholesterol (HDL$\mathrm{C})$, and low-density lipoprotein-cholesterol (LDLC) levels in hyperlipidemic group (HCG) treated for $18 \mathrm{~h}$ are shown in (Figure 2). Triton WR-1339 caused a significant increase in plasma TC, LDLC $(p<0.001)$, and TG $(p<0.0001)$ levels, and a significant decrease in HDL-C level $(p<0.001)$ in hyperlipidemic control group (HCG) after $18 \mathrm{~h}$ of Triton WR-1339 administration in comparison with the normal control group (NCG).<smiles>Cc1ccc(C(=O)Nc2ccc(C(=O)c3ccccc3)cc2)o1</smiles> 
Scheme 2: Synthesis of N-(benzoylphenyl)-5-methyl-2-furamides (4a, 4b and 4c). Reagents and condition: (i): DMAP, DCM/ reflux, $24 \mathrm{~h}$

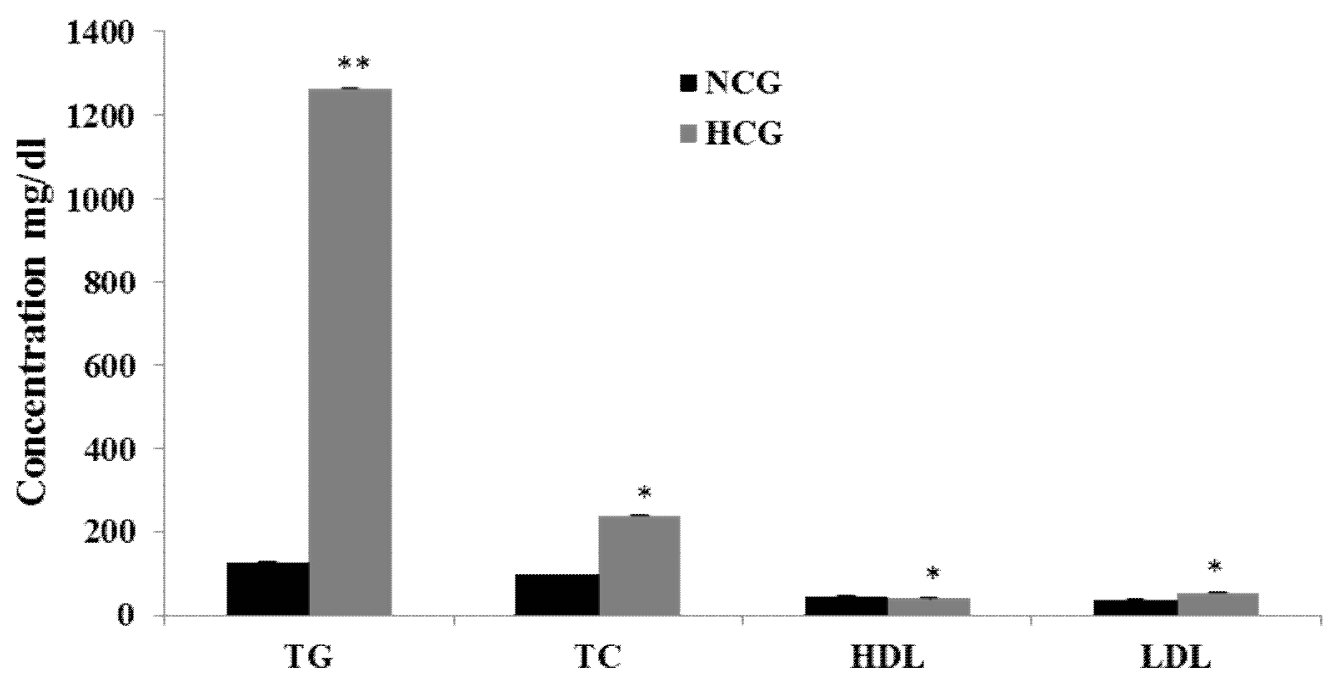

Figure 2: Effect of Triton WR-1339 on plasma lipid profile after $18 \mathrm{~h}$. Values are means \pm SEM from eight animals in each group. NCG, control group; HCG, hyperlipidemic control group; TG, triglyceride; TC, total cholesterol; HDL-C, high density lipoprotein-cholesterol; LDL-C, low-density lipoprotein cholesterol. HCG is compared to NCG. ${ }^{*} p<0.001, .{ }^{* *} p<0.0001$

The increase of plasma total cholesterol concentration in the HCG was $147 \%$ after $18 \mathrm{~h}$ as compared to the NCG. Triglyceride level in the HCG was also elevated by $887 \%$ after $18 \mathrm{~h}$. At the same time, LDL-C level in HCG was also elevated by $49 \%$ after $18 \mathrm{~h}$ as compared to the NCG. HDL level in HCG was decreased by $14 \%$ after $18 \mathrm{~h}$ as compared to NCG.

\section{Effect of compounds $3 b, 4 b, 4 c$ and BF on plasma lipid profile in rats}

The effect of compounds $\mathbf{3 b}, \mathbf{4 b}, \mathbf{4 c}$ and $\mathbf{B F}$ on plasma lipid profile on treated rats after $18 \mathrm{~h}$ are shown in Table 1. Interestingly, the elevated plasma TG levels produced by the acute injection of Triton WR-1339 were significantly $(p<0.0001)$ decreased by 71 and $67.5 \%$ in compounds 4c and BF respectively and by $56 \%$ in $\mathbf{4 b}(p<$ 0.001 ) after $18 \mathrm{~h}$, in comparison to Triton treated hyperlipidemic control (HCG). Furthermore, total cholesterol levels were significantly $(p<0.01)$ reduced in 4 b by $49 \%$ and in 4 c $(p<0.001)$ by
$50 \%$ after $18 \mathrm{~h}$ compared to hyperlipidemic control group (HCG).

After $18 \mathrm{~h}$ of treatment, LDL-cholesterol levels were lowered by $(49 \%, p<0.0001)$ in $4 c$ and (43.6\% $p<0.001$ ) in compound 4b (Table 1). The HDL-C levels were significantly $(p<0.001)$ increased in compounds $4 \mathrm{c}$ and BF by 34 and $36.5 \%$ respectively and in 4 b by $29 \%(p<0.01)$ after $18 \mathrm{~h}$ compared to HCG treated rats. No significant differences in TC, TG, HDL-C and LDL-C levels were observed by compound $\mathbf{3 b}$ in treated rats after $18 \mathrm{~h}$ compared to HCG-treated rats.

\section{DISCUSSION}

The results of the present study revealed the potential anti-hyperlipidemic activity of novel series of $N$-(benzoylphenyl)-2-furamides using Triton WR-1339-induced hyperlipidemic rats as a model for screening the lipid lowering potential [22].

Table 1: Effect of compounds $\mathbf{3 b}, \mathbf{4 b}, \mathbf{4 c}$ and $\mathbf{B F}$ on plasma lipid levels in Triton WR 1339 induced hyperlipidemic rats after $18 \mathrm{~h}$

\begin{tabular}{lcccc}
\hline Compound & TG [mg/dl] & TC [mg/dl] & HDL [mg/dl] & LDL [mg/dl] \\
\hline HCG & $1264 \pm 22.0$ & $240 \pm 9.0$ & $41 \pm 2.3$ & $55 \pm 1.3$ \\
3b & $1224 \pm 21.0$ & $242 \pm 5.0$ & $42 \pm 2.7$ & $52 \pm 3.5$ \\
4b & $553 \pm 12.0^{\mathrm{D}}$ & $122 \pm 2.0^{\mathrm{a}}$ & $53 \pm 2.75^{\mathrm{a}}$ & $31 \pm 1.0^{\mathrm{b}}$ \\
4c & $371 \pm 5.0^{\mathrm{C}}$ & $119 \pm 4.0^{\mathrm{D}}$ & $55 \pm 3.2^{\mathrm{b}}$ & $28 \pm 2.1^{\mathrm{C}}$ \\
BF & $411 \pm 3.0^{\mathrm{C}}$ & $235 \pm 2.0$ & $56 \pm 5.0^{\mathrm{a}}$ & $52 \pm 1.6$ \\
\hline
\end{tabular}

Values are means \pm SEM from eight animals in each group. NCG: normal control group; HCG: hyperlipidemic control group; 3b: hyperlipidemic plus 3b; 4b: hyperlipidemic plus 4b; 4c: hyperlipidemic plus 4c; BF: hyperlipidemic plus Bezafibrate. TC: total cholesterol; TG: triglyceride; HDL-C: high-density lipoprotein 
cholesterol; LDL-C: low density lipoprotein cholesterol. 3b, 4b, 4c and BF are compared with HCG a $p<0.01,{ }^{b} p$ $<0.001,{ }^{c} p<0.0001$

Our results showed that the hyperlipidemia induced by Triton WR-1339 was significantly reduced by compounds $\mathbf{4 b}, \mathbf{4 c}$, and bezafibrate in comparison with the hyperlipidemic control group after $18 \mathrm{~h}$. It was not surprising that the reduction in triglycerides levels of compounds $\mathbf{4 b}$ and $\mathbf{4 c}$ were significantly greater than the reduction in cholesterol levels; this could be explained by the significant elevation in plasma lipid profile following Triton WR-1339 administration which results mostly from the increase in VLDL (in which the triglycerides portion is several times greater than that of cholesterol) [23]. This result suggests that the compounds are able to restore, at least partially, the catabolism of lipoproteins.

In addition, $\mathbf{4 b}$ and $\mathbf{4 c}$ significantly increased the HDL-C levels after $18 \mathrm{~h}$ of Triton WR-1339 administration. Elevated HDL-C is reported to have a preventive action against atherogenesis [24].

The findings of this research work are in agreement with our previous data which indicated that the presence of an aromatic heterocyclic moiety connected to huge lipophilic aromatic rings through a carboxamide linkage is necessary for interaction with proper target(s) for hypolipidemic activity $[25,26]$. Also, the chemical nature and the electronic effect of the substituents bearing on the heterocycle ring play an important role in the determination of activity.

In the present study, the aromatic heterocycle is represented by furan ring and the aromatic lipophilic rings are benzophenones as shown in compounds $\mathbf{3 b}, \mathbf{4 b}$ and $\mathbf{4 c}$. Compounds $\mathbf{4 b}$ and 4c demonstrated much more activity than $\mathbf{3 b}$. This result may be explained by the chemical nature of the substituent on position 5 of the furan ring. In compounds $\mathbf{4 b}$ and $\mathbf{4 c}$, the substituent is methyl group, a small lipophilic group while compound $\mathbf{3 b}$ harbors a phenolic group that offers $\mathrm{H}$-bond donor and acceptor motif. The size of the substituent on position 5 is a determinant for the activity and this result may indicate that the adjacent area in the target(s) which receives the furan ring is a small lipophilic site. Therefore, the presence of methyl group provides good hydrophobic interaction in the binding cleft. Interestingly, 4c exhibited better activity than $\mathbf{4 b}$ and this may be attributed to the possibility of intramolecular $\mathrm{H}$-bond interaction which in turn affects drug/receptor interaction and thus, might infer that the binding site is lipophilic.
At the same time, if compounds $\mathbf{4 b}$ with $\mathbf{4 c}$ are compared, $\mathbf{4 c}$ is more active than $\mathbf{4 b}$ and this may be due to the possibility of intramolecular hydrogen bond formation which means that the amide hydrogen and the oxygen atom of the keto group are not involved in hydrogen bond formation with the target(s); this may suggest that the area in the active site of the target(s) which accommodates the ligand is lipophilic in nature.

\section{CONCLUSION}

Compounds $4 \mathrm{~b}$ and $4 \mathrm{c}$ improve lipid profile in Triton-induced hyperlipidemic rats. These findings are in agreement with previous reports, and thus confirm that the presence of lipophilic moiety, carboxamide linkage and a heterocyclic ring (capable of hydrogen bond formation, furan ring) are three important requirements for the hypolipidemic activity of these novel compounds. Thus, there is a need for further investigations to elucidate the exact mechanism of action of these compounds which can serve as lead compounds in the search for therapeutic agents for targeting dyslipidemia and cardiovascular diseases.

\section{DECLARATIONS}

\section{Acknowledgement}

The authors wish to express their sincere appreciation to Al-Zaytoonah University of Jordan for financial support.

\section{Conflict of Interest}

No conflict of interest associated with this work.

\section{Contribution of Authors}

The authors declare that this work was done by the authors named in this article and all liabilities pertaining to claims relating to the content of this article will be borne by them.

\section{Open Access}

This is an Open Access article that uses a funding model which does not charge readers or their institutions for access and distributed under the terms of the Creative Commons Attribution License (http://creativecommons.org/licenses/by 14.0) and the Budapest Open Access Initiative (http://www.budapestopenaccessinitiative.org/rea 
d), which permit unrestricted use, distribution, and reproduction in any medium, provided the original work is properly credited.

\section{REFERENCES}

1. Sunil C, Ignacimuthu S, Kumarappan C. Hypolipidemic activity of Symplocos cochinchinensis S. Moore leaves in hyperlipidemic rats. J Nat Med 2012; 66: 32-38.

2. Ginghina $C$, Bejan I, Ceck CD. Modern risk stratification in coronary heart disease. J Med Life 2011; 4: 377-386.

3. Bahmani $M$, Mirhoseini $M$, Shirzad $H$, Sedighi $M$, Shahinfard N, Rafieian-Kopaei M. J Evid Based Complementary Altern Med 2015; 7: 483-492.

4. Rohilla A, Dagar N, Rohilla S, Dahiya A, Kushnoor A. Hyperlipidemia- a deadly pathological condition. IJCPR 2012; 4: 15-18.

5. McQueen MJ, Hawken S, Wang X, Ounpuu $S$, Sniderman A, Probstfield J, Steyn K, Sanderson JE, Hasani $M$, Volkova $E$, et al. Lipids, lipoproteins, and apolipoproteins as risk markers of myocardial infarction in 52 countries (the INTERHEART study): a case-control study. Lancet 2008; 372: 224-333.

6. Smilde TJ, Van Wissen $S$, Wollersheim $H$, Trip MD, Kastelein JJ, Stalenhoef AF. Effect of aggressive versus conventional lipid lowering on atherosclerosis progression in familial hypercholesterolaemia (ASAP): a prospective, randomised, double-blind trial. Lancet 2001; 357: 577-581.

7. Hayashi $H$, Niinobe $S$, Matsumoto $Y$, Suga $T$. Effects of Triton WR-1339 on lipoprotein lipolytic activity and lipid content of rat liver lysosomes. J Biochem 1981; 89:573579.

8. Schotz MC, Scanu A, Page IH. Effect of Triton on lipoprotein lipase of rat plasma. Am J Physiol 1957; 188 : 399-402.

9. Schurr PE, Schultz JR, Parkinson TM. Triton induced hyperlipidaemia in rats as an animal model for screening hypolipidemic drugs. Lipids 1972; 7: 69-74.

10. Abourbih S, Filion KB, Joseph L, Schiffrin EL, Rinfret $S$, Poirier P, Pilote L, Genest J, Eisenberg MJ. Effect of fibrates on lipid profiles and cardiovascular outcomes: a systematic review. Am J Med 2009; 122: 962.e1962.e8.

11. de Man F.H., F. de Beer, A. van der Laarse, H. Jansen, J.A. Leuven, J.H. Souverijn, Vroom TF, Schoormans SC, Fruchart JC, Havekes LM, Smelt AH. The hypolipidemic action of bezafibrate therapy in hypertriglyceridemia is mediated by upregulation of lipoprotein lipase: no effects on VLDL substrate affinity to lipolysis or $L D L$ receptor binding. Atherosclerosis 2000; 153: 363-371.

12. Al-Najdawi M, Al-Hiari Y, Al-Qirim T, Shattat G, Al-Zweri M, Abu Sheikha G. Synthesis and pharmacological evaluation of novel unsubstituted indole-anthraquinone carboxamide erivatives as potent antihyperlipidemic agents. Z Naturforsch C 2014; 69: 21-28.
13. Koh KK, Quon MJ, Rosenson RS, Chung WJ, Han SH. Vascular and metabolic effects of treatment of combined hyperlipidemia: focus on statins and fibrates. Int $J$ Cardiol 2008; 124: 149-159.

14. Schoonjans K, Staels B, Auwerx J. Role of the peroxisome proliferator-activated receptor (PPAR) in mediating the effects of fibrates and fatty acids on gene expression. J Lipid Res 1996; 37: 907-925.

15. Al-Qirim T, Shattat G, Sheikha GA, Sweidan K, Al-Hiari $Y$, Jarab A. Synthesis of Novel N-(4-benzoylphenyl)-2furamide Derivatives and their Pharmacological Evaluation as Potent Antihyperlipidemic Agents in Rats. Drug Res (Stuttg) 2014; 65: 158-163.

16. Al-Qirim T, Shattat G, Sweidan K, El-Huneidi W, Abu Sheikha G, Abu Khalaf $R$, Hikmatet $S$. In Vivo Antihyperlipidemic Activity of a New Series of $\mathrm{N}$ (Benzoylphenyl) and N-(Acetylphenyl)-1-benzofuran-2carboxamides in Rats. Arch Pharm (Weinheim) 2012; 345: 401-406.

17. Shattat G, Al-Qirim T, Abu Sheikha G, Al-Hiari $Y$, Sweidan K, Al-Qirim R, Hikmat S, Hamadneh L, Al-Kouz $S$. The pharmacological effects of novel 5-fluoro- $\mathrm{N}$ (9,10-dihydro- 9,10-dioxoanthracen-8-yl)-1H-indole-2carboxamide derivatives on plasma lipid profile of TritonWR-1339-induced Wistar rats. J Enzyme Inhib Med Chem 2013; 28: 863-869.

18. European Commission. Comparison recommendation of 18 June 2007 on guidelines for the accomodation and care of animals used for experimental and other scientific purpose. OJEU 2007; 50: L1-L197.

19. Abu Sheikha G, Hussin B, Al-Hiari Y, Al-Qirim T, Shattat $G$. Synthesis of Benzothiophene Carboxamide Derivatives and their Pharmacological Evaluation as Potent Antihypertriglyceridemic Agents in Rats. Z Naturforsch C 2011; 66c: 93-103.

20. Nakajima $T$, Tanaka $N$, Kanbe $H$, Hara A, Kamijo $Y$, Zhang X, Gonzalez FJ, Aoyama T. Bezafibrate at clinically relevant doses decreases serum/liver triglycerides via down-regulation of sterol regulatory element-binding protein-1c in mice: a novel peroxisome proliferator-activated receptor alpha-independent mechanism. Molecular Pharmacol 2009; 75: 782-792.

21. Mori Y, Tokutate Y, Oana F, Matsuzawa A, Akahane S, Tajima N. Bezafibrate-induced changes over time in the expression of uncoupling protein (UCP) mRNA in the tissues: a study in spontaneously type 2 diabetic rats with visceral obesity. J Atheroscler Thromb 2004; 11: 224-231.

22. Kalopissis A D, Griglio S, Malewiak MI, Rosen R. Effect of a high-fat diet on rat very low density lipoprotein secretion. Biochim Biophys Acta 1980; 620: 111 - 119.

23. Perez C, Canal JR, Campillo JE, Romero A, Torres MD. Hypotriglyceridemic activity of Ficus carica leaves in experimental hypertriglyceridemic rats. Phytother Res 1999; 13:188-191.

24. Malloy MJ, Kan JP. Medical management of hyperlipidemic states. Adv Int Med 1994; 39: 603-631. 
Hikmat et al

25. Al-Qirim T, Shahwan M, Shattat G, Al-Hiari $Y$, Abu Sheikha G, Zaidi S. Pharmacological evaluation of novel indole-2-carboxamides as potent lipidlowering agents in Triton-WR1339-induced hyperlipidemic rats. Z Naturforsch 2009; 64c: 619-625.
26. Shattat G, Al-Qirim R, Al-Hiari Y, Abu Sheikha G, AlQirim T, El-Huneidi W, Shahwan M. Synthesis and antihyperlipidemic evaluation of $\mathrm{N}$-(benzoylphenyl)- 5fluoro-1H-indole-2-carboxamide derivatives in Triton WR-1339-induced hyperlipidemic rats. Molecules 2010; 15: $5840-5849$. 